\title{
Performance, organ growth and economics of finisher broiler fed neem (Azadirachta indica) leaf meal as replacement for maize
}

Olowu ${ }^{1}$, O.P.A., Asaniyan, ${ }^{2 *}$ E.K. and Agbede, ${ }^{3}$ J.O.

${ }^{1}$ Department of Animal Production, Federal College of Agriculture, Akure, Nigeria ${ }^{2}$ Department of Animal Science and Livestock Production, Joseph Ayo Babalola University Ikeji-Arakeji P.M.B.5006, Ilesa, Nigeria. ${ }^{3}$ Department of Animal Production and Health, Federal University of Technology, P.M.B.704, Akure, Nigeria. *E-mail: depaul42k@yahoo.com

\begin{abstract}
A 28-day feeding trial was conducted to evaluate the effects of dietary inclusion of neem (Azadirachta indica) leaf meal on the performance, organ growth and economics of finishing broilers. The harvested neem leaves were chopped and air dried under room temperature for ten days until they became crispy while retaining the greenish colouration. The dry leaves were hammer milled with $2 \mathrm{~mm}$ sieve to produce leaf meal before being incorporated into broiler finisher diets. Four isonitrogenous finisher diets were formulated; containing $0 \%, 5 \%, 10 \%$ and $15 \%$ levels of neem leaf meal (NLM) as partial replacement for maize in the diets. A total of one hundred and eight (108) 4week old birds were randomly selected, weighed and assigned to the four treatments in a complete randomised design. The four treatments were replicated three times with nine (9) birds per replicate. The birds were fed ad libitum with their respective diets and freely supplied with water. Results showed that the neem leaf levels significantly $(P<0.05)$ affected all the performance indicators. Birds on 5\% NLM had similar average daily weight gain, average daily feed intake and feed conversion ratio (FCR) with birds on $0 \%$ neem leaf meal (control) but significantly $(P<0.05)$ superior to birds on $10 \%$ and $15 \%$ neem leaf meal levels. On the relative organ weight, except for the heart, all the organs were not significantly $(P>0.05)$ affected by the varying levels of neem leaf meal. The g/kgbody weight of the heart reduces as the level of NLM increases; with 15\% NLM having the least heart weight $(7.50 \pm 0.47 \mathrm{~g} / \mathrm{kgbody}$ weight). The cost analysis of replacing maize with neem leaf meal in the broiler finisher diets revealed that 15\% level yielded least cost of feed consumed per bird (? 178.69), cost of feed consumed per kg body weight per day (? 6.38) and cost of feed per kg weight (? 55.84). It is concluded that 5\% replacement level of maize will enhance optimum performance and organ growth while 10\% NLM brings about the optimum cost benefit in feeding finisher broilers with neem leaf meal.
\end{abstract}

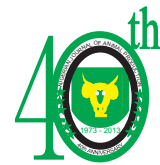

Key words: Neem leaf meal, maize, replacement level, performance, finisher broilers

\section{Introduction}

Poultry remains relatively affordable source of animal protein with high biological value for human consumption in both rural and urban societies of Nigeria. However, the high cost of poultry feed constituted a great challenge against poultry production and consumption. In facing this challenge, poultry nutritionists are unrelently making efforts in cutting down the high cost of feed. This led to several efforts in exploiting unconventional feed ingredients with little or no nutritional competition from man as strategy against the existing situation with the conventional feed ingredients; that culminated to high cost of feed. The need for alternative sources of feed has led to the exploitation of leaf meals of some tropical legumes and browse plants as ingredients in poultry diets (Obikaonu, 2012). Neem has been identified among the tropical plant that can be used as livestock feed resource (Kausik et al., 2008 and Ogbuewu et al., 2009). Neem (Azadirachta indica) is an indigenous tropical plant, which 


\section{Performance and economics of finisher broiler fed Neem leaf meal}

predominate in Nigeria. Commonly known as "don goyaro"; popular for its medicinal potentials in Southern Nigeria and grown in the North principally to reduce the rate of desertification. Neem has attracted worldwide prominence due to its vast range of medicinal properties such as antibacterial, antiviral, antifungal, antiprotozoal, hepatoprotective and various other properties without showing any adverse effects (Kale et al., 2003). Neem leaves like most tropical tree leaves contain bioactive compounds (Kausik et al., 2008) which may affect nutrient utilization. Neem leaf meal has nutritional and health improvement potential as a feed ingredient in broiler production without compromising the haematological parameters, carcass characteristics and meat taste (Bonsu et al, 2012). Esonu et al. (2006) reported that neem leaf meal has a proximate composition of $92.40 \%$ dry matter; $7.58 \%$ moisture; $20.69 \%$ crude protein; $16.60 \%$ crude fibre; $4.13 \%$ ether extract; $7.10 \%$ Ash and $43.91 \%$ Nitrogen free extract but Bakshi et al. (2006) reported it to be low in metabolisable energy $(0.34 \mathrm{KJ} / \mathrm{Kg} \mathrm{DM})$. However, Ogbuewu et al. (2010) reported that neem leaves contain appreciable amount of proteins, minerals, carotene and adequate amount of trace minerals.

The inclusion of neem leaf meal in the diet of starter broiler chickens should not exceed 5\% since inclusion levels beyond this suppressed their feed intake and growth rate (Obikaonu, 2009). Obikaonu (2012) similarly reported the same 5\% inclusion level of neem leaf meal in the diet of finisher broilers. However, this study is designed to appraise the performance, organ growth and economics of finishing broiler chickens fed diets containing graded levels of neem leaf meal in partial replacement of maize.

\section{Material and Methods}

Experimental plan: This study was carried out at the Poultry Unit of the Teaching Farm of Federal College of Agriculture, Akure; located at latitude $07^{\circ} 17^{\prime} \mathrm{N}$ and longitude $05^{\circ} 18^{\prime} \mathrm{E}$. The mean annual rainfall and mean annual temperature for the location were $133 \mathrm{~mm}$ and $29^{\circ} \mathrm{C}$ respectively. Fresh matured neem leaves were harvested within the College compound. The leaves were chopped without the petioles for effective drying. The chopped leaves were air dried at room temperature for ten days until they became crispy while retaining the greenish colouration. The dry leaves were milled into $2 \mathrm{~mm}$ size using a locally manufactured hammer mill to produce leaf meal before being incorporated into broiler finisher diets. Four isonitrogenous finisher diets were formulated; containing different levels of neem leaf meal (NLM). The four experimental diets (treatments) were composed of $0 \%, 5 \%, 10 \%$ and $15 \%$ neem leaf meal as partial replacement for maize in the diets (Table 1). One hundred and fifty (150) day old Anak broiler chicks purchased from Zartech Nigeria Limited, Ibadan were electrically brooded. The birds were majorly vaccinated against Newcastle disease and given appropriate prophylactic medications against coccidiosis and stress; feed (commercial starter diet with $22 \% \mathrm{CP}$ and $2900 \mathrm{Kcal} / \mathrm{KgME}$ ) and water were given ad libitum. At the end of the preexperimental period that lasted four weeks (4); a total of one hundred and eight (108) of the birds were randomly selected, weighed and assigned to the four treatments in a completely randomised design. The four treatments were replicated three times with nine (9) birds per replicate. The birds were brooded and raised in nine equidimensional pens $(1 \mathrm{~m} \times 1 \mathrm{~m})$ within a deep litter house. The birds were fed ad libitum with their respective diets and freely 
Olowu, Asaniyan, and Agbede

Table 1: Percentage composition of ingredients in the experimental diets

\begin{tabular}{lcccc}
\hline \multirow{2}{*}{ Ingredients } & \multicolumn{4}{c}{ Percentage level of neem leaf meal inclusion } \\
\cline { 2 - 5 } & $0 \%$ & $5 \%$ & $10 \%$ & $15 \%$ \\
\hline Maize & 56.95 & 45.45 & 41.94 & 38.55 \\
Neem leaf meal & 0.00 & 11.50 & 15.01 & 18.40 \\
Soybean meal & 33.02 & 33.02 & 33.02 & 33.02 \\
Brewer dry grain & 5.00 & 5.00 & 5.00 & 5.00 \\
Palm oil & 1.00 & 1.00 & 1.00 & 1.00 \\
Bone meal & 2.50 & 2.50 & 2.50 & 2.50 \\
Oyster shell & 0.50 & 0.50 & 0.50 & 0.50 \\
Methionine & 0.03 & 0.03 & 0.03 & 0.03 \\
Broiler premix & 0.50 & 0.50 & 0.50 & 0.50 \\
Salt & 0.50 & 0.50 & 0.50 & 0.50 \\
Total & 100 & 100 & 100 & 100 \\
\hline Proximate composition $(\%)$ & & & 87.23 \\
\hline Dry matter & 86.22 & 86.85 & 87.04 & 20.32 \\
Crude protein & 20.48 & 20.25 & 20.63 & 4.78 \\
Crude fibre & 4.27 & 4.59 & 4.68 & 4.82 \\
Ether extract & 3.97 & 4.50 & 4.67 & 3.29 \\
Ash & 2.38 & 2.95 & 3.12 & 51.07 \\
Nitrogen free extract & 54.35 & 52.30 & 51.68 & \\
\hline
\end{tabular}

supplied with water under healthy management practices. The record of average weekly weight gain and average daily feed consumption were kept and feed conversion ratio computed. The feeding trial lasted 28 days.

Organs measurement: At the end of the feeding trial, two birds were randomly selected per replicate; weighed, stunned and slaughtered by severing the jugular veins with a sharp surgical knife. After slaughtering and bleeding, the carcasses were scalded at $65^{\circ} \mathrm{C}$ in water bath for 30 seconds before defeathering. The carcasses were later eviscerated, dissected and organs measured. The organs measured were the liver, heart, lungs, spleen, pancreas, kidney, bursa, crop and gizzard. All the organs measured were expressed as $\mathrm{g} / \mathrm{kg}$ body weight.

Cost Analysis: The cost analysis of the birds' consumption level in relation to the formulated experimental diets was carried out based on the estimated cost of milling the dried neem leaf and prevailing prices of the other component ingredients.

Proximate and Statistical Analysis: The proximate composition of the neem leaf meal (Table 2) and the experimental diets were determined as described by AOAC (1995) methods. Data collected in the course of the study were subjected to analysis of variance and treatment means separated by Duncan's Multiple Range Test using SPSS 17.0.1 Version (2008).

\section{Results}

The result of the treatment effects on the broiler performance showed that average final body weight, average weight gain, average daily body weight gain, average daily feed intake and feed conversion ratio were significantly $(\mathrm{P}<0.05)$ affected by varying dietary levels of neem leaf meal as presented in Table 3. The 0 and 5\% dietary levels of neem leaf meal were not significantly $(\mathrm{P}>0.05)$ different from one another in their influence on all the performance indicators. Birds on 0 and $5 \%$ 
Table2: Proximate composition of neem leaf meal

\begin{tabular}{ll}
\hline Components & Percentage \\
\hline Dry matter & 93.66 \\
Crude protein & 19.79 \\
Crude fibre & 5.46 \\
Ether extracts & 6.74 \\
Ash & 5.68 \\
Nitrogen free extract & 55.99 \\
\hline
\end{tabular}

neem leaf meal were significantly $(\mathrm{P}<0.05)$ different from those on 10 and $15 \%$. However, birds on 10 and $15 \%$ neem leaf meal showed significant $(\mathrm{P}<0.05)$ difference in average body weight gain and average daily weight gain while other performance indicators were not significantly affected. Table 4 presents relative organ weight of broiler chicken as affected by varying levels of neem leaf meal. Except for the heart, all the organs were not significantly $(\mathrm{P}>0.05)$ affected by the varying levels of neem leaf meal. Birds on $0 \%$ neem leaf meal had the highest heart weight, significantly $(\mathrm{P}<0.05)$ different from others. The heart weights on 5 and $10 \%$ neem leaf meal were not significantly different from one and another but 15\% neem leaf meal had the least heart weight
(7.80 $\pm 0.47 \mathrm{~g} / \mathrm{kg}$ body weight), significantly $(\mathrm{P}<0.05)$ different from others. Table 5 presents the cost analysis of replacing maize with neem leaf meal in the broiler finisher diets. For the 28 days period of the trial, diet with $0 \%$ neem leaf meal (control) had the highest cost of feed $/ \mathrm{kg}$ ( $\$ 64.40)$ followed by 5\% ( 559.24), 10\% ( $\$ 57.56)$ neem leaf diets while $15 \%$ neem leaf diet had the least cost of feed/kg ( 155.84$)$. The cost of feed consumed $/ \mathrm{kg}$ weight of bird (CFC/ kg weight of bird) and cost of feed/kg weight/day followed the same trend as cost of feed $/ \mathrm{kg}$. The $0 \%$ neem leaf meal diet numerically had the highest value (N223.47) for CFC/ $\mathrm{kg}$ weight of bird while $15 \%$ neem leaf meal diet had the least value (\$178.69).

\section{Discussion}

The non significant influence of dietary treatments on the performance indicators of the broilers tend to show that neem leaf meal inclusion in broiler diets at the finisher phase seems to have similar contribution to broiler performance; with birds under 5\% NLM exhibited optimum performance that compared favourably with the control diet $(0 \% \mathrm{NLM})$. Also, the performance pattern

Table 3: Performance of Broiler Chicken fed varying dietary levels of Neem Leaf Meal (NLM)

\begin{tabular}{|c|c|c|c|c|}
\hline & \multicolumn{4}{|c|}{ Dietary Treatments (\% Inclusion level of NLM) } \\
\hline Parameter & 0 & 5 & 10 & 15 \\
\hline $\begin{array}{l}\text { Average Initial Body } \\
\text { Weight }(\mathrm{g})\end{array}$ & $1460.00^{\mathrm{a}} \pm 57.82$ & $1442.59^{\mathrm{a}} \pm 60.94$ & $\begin{array}{r}1470.37^{\mathrm{a}} \pm \\
87.20\end{array}$ & $1453.70^{\mathrm{a}} \pm 77.44$ \\
\hline $\begin{array}{l}\text { Average Final Body } \\
\text { Weight }(\mathrm{g})\end{array}$ & $2242.00^{\mathrm{a}} \pm 114.17$ & $2197.21^{\mathrm{a}} \pm 56.48$ & $\begin{array}{r}2014.81^{\mathrm{b}} \pm \\
99.59\end{array}$ & $1790.74^{b} \pm 167.08$ \\
\hline $\begin{array}{l}\text { Average Body Weight } \\
\text { Gain (g) }\end{array}$ & $782.22^{\mathrm{a}} \pm 9.34$ & $754.21^{\mathrm{a}} \pm 6.53$ & $544.53^{b} \pm 3.51$ & $336.84^{\mathrm{c}} \pm 3.81$ \\
\hline $\begin{array}{l}\text { Average Daily Body } \\
\text { Weight Gain }(\mathrm{g})\end{array}$ & $37.24^{\mathrm{a}} \pm 2.95$ & $35.01^{\mathrm{a}} \pm 0.65$ & $25.93^{\mathrm{b}} \pm 1.34$ & $16.04^{\mathrm{c}} \pm 0.32$ \\
\hline $\begin{array}{l}\text { Average Daily Feed } \\
\text { Intake Weight }(\mathrm{g})\end{array}$ & $165.56^{\mathrm{a}} \pm 0.45$ & $160.15^{\mathrm{a}} \pm 2.91$ & $157.86^{\mathrm{b}} \pm 1.39$ & $152.51^{\mathrm{b}} \pm 0.32$ \\
\hline $\begin{array}{l}\text { Feed Conversion Ratio } \\
\text { (FCR) }\end{array}$ & $4.44^{\mathrm{a}} \pm 0.50$ & $4.57^{\mathrm{a}} \pm 0.92$ & $6.08^{\mathrm{bc}} \pm 0.82$ & $9.55^{\mathrm{c}} \pm 21.01$ \\
\hline
\end{tabular}


of the birds revealed that various inclusion levels of neem leaf meal experimented in this study might have enhanced the health integrity of the bird. This can be attributed to the presence of quercetin (flavonoid) in neem leaf, reported to have antibacterial and antifungal properties (Elangovan et al., 2000). Hence, promotes the medicinal benefits that culminated into good performance in broiler chickens. The heart significantly decreased in weight at $15 \%$ NLM level. Implying that NLM inclusion had the potential of preventing finisher broilers against cardiac hypertrophy and enhances the functional integrity of the heart. This tends to reveal the benefit of reported anti-inflammatory properties of neem (Schumacher et al, 2011). This tends to corroborate the report of Bonsu et al. (2012) that neem leaf meal has both nutritional and health improvement potential as a feed ingredient in broiler production. The NLM inclusion levels are inversely proportional to cost variables; cost of feed consumed $/ \mathrm{kg}$ weight of bird and cost of feed consumed / $\mathrm{kg}$ weight of bird/day, this tend to show that replacement of maize with neem leaf meal will possibly

Table 4: Relative organ weight of broiler chicken fed Neem Leaf Meal (NLM) (g/kg body weight)

\begin{tabular}{|c|c|c|c|c|c|}
\hline \multicolumn{6}{|c|}{ Dietary treatments ( $\%$ Inclusion level of NLM) } \\
\hline Parameter & & $0 \%$ & $5 \%$ & $10 \%$ & $15 \%$ \\
\hline Heart & & $12.25^{\mathrm{a}} \pm 1.75$ & $10.60^{\mathrm{b}} \pm 0.91$ & $9.26^{\mathrm{b}} \pm 1.18$ & $7.80^{\mathrm{c}} \pm 0.47$ \\
\hline Lungs & “ & $15.21 \pm 2.20$ & $12.59 \pm 1.12$ & 10.992 .09 & $11.85 \pm 1.71$ \\
\hline Liver & “ & $55.64 \pm 5.34$ & $43.66 \pm 3.17$ & 43.441 .80 & $41.70 \pm 2.36$ \\
\hline Spleen & “ & $2.55 \pm 0.60$ & $2.34 \pm 0.58$ & 1.810 .37 & $1.82 \pm 0.50$ \\
\hline Pancreas & “ & $4.66 \pm 0.72$ & $5.46 \pm 1.02$ & 3.730 .22 & $5.01 \pm 0.55$ \\
\hline Kidney & “6 & $9.25 \pm 5.49$ & $13.51 \pm 1.68$ & 6.382 .84 & $14.07 \pm 0.61$ \\
\hline Gizzard & “" & $57.01 \pm 3.29$ & $48.93 \pm 5.91$ & 43.234 .41 & $52.00 \pm 0.29$ \\
\hline Bursa & “ & $0.94 \pm 0.28$ & $2.30 \pm 1.01$ & 1.030 .74 & $1.89 \pm 0.85$ \\
\hline Crop & “ & $9.92 \pm 0.88$ & $9.22 \pm 1.91$ & 6.430 .26 & $6.62 \pm 0.31$ \\
\hline
\end{tabular}

Means \pm SD

${ }^{a, b, c}$ Means with different superscript in the same row are significantly different $(\mathrm{P}<0.05)$

Table 5: Cost analysis of Neem Leaf Meal (NLM) utilization in place of maize

\begin{tabular}{lccccc}
\hline $\begin{array}{l}\text { Inclusion } \\
\text { level of NLM } \\
(\%)\end{array}$ & $\begin{array}{l}\text { TFC/kg } \\
\text { body } \\
\text { weight }\end{array}$ & $\begin{array}{c}\text { Cost of feed/kg } \\
(\mathrm{N})\end{array}$ & $\begin{array}{c}\text { CFC/kg } \\
\text { weight } \\
(\mathrm{N})\end{array}$ & $\begin{array}{c}\text { body } \\
\text { CFC/kg } \\
\text { weight/day } \\
(\mathrm{N})\end{array}$ & body \\
\hline 0 & 3.47 & 64.40 & 223.47 & 7.98 & \\
5 & 3.36 & 59.24 & 199.05 & 7.11 & \\
10 & 3.31 & 57.56 & 190.52 & 6.80 & \\
15 & 3.20 & 55.84 & 178.69 & 6.38 & \\
\hline TFC - Total Feed Consumed & & & &
\end{tabular}


reduce the cost of feeding broilers at finisher phase. This confirmed the report of Esonu et al., 2002; that leaf meal is one of the possible cheap feed resources.

\section{Conclusion}

The outcome of this study revealed that 5\% replacement level of maize with neem leaf meal (NLM) promoted optimum performance and organ growth but $10 \%$ level yielded optimum cost of feed consumed per kg weight of bird, cost of feed consumed per kg weight of bird per day and cost of feed per $\mathrm{kg}$ weight. It can then be concluded that within the limit of this study, $5 \%$ neem leaf meal inclusion will enhance optimum performance and organ growth in finisher broilers. However, sustainable optimum cost of using neem leaf meal can be achieved when neem plant is grown as ornamental crop within the immediate environment rather than collecting the leaves or paying the producers to gather it.

\section{References}

AOAC 1995. Official Method of Analysis. Association of Officiating Analytical Chemist, Washington D.C.

Bakshi, M.P.S., Wadha, M. and Rana, K. K. 2006. Nutritive value of tree leaves for livestock from a semihilly arid region of India. In: Improving productivity by supplementary feeding of multinutrient blocks, controlling internal parasites and enhancing utilization of alternate feed resources.

Bonsu, F.R.K. Kagya-Agyemang, J.K. Kwenin, W.K.J. and Zanu, H.K. 2012. Medicinal Response of Broiler Chickens to Diets Containing Neem(Azadirachta indica) Leaf Meal, Haematology and Meat Sensory Analysis. World Appl. Sci. J., 19 (6): 800-805.
Elangovan, A.V., S.V.S. Verma, V.R.B. Sastry and S. Singh, 2000. Effect of feeding Neem (Azadirachta indica) kernel meal on growth, nutrient utilization and physiology of Japanese quails (Cortunix cortunix japonica). Asian-Aust. J. Anim Sci., 13: 125- 128.

Esonu, B.O., Opara, M.N., Okoli, I.C., Obikaonu, H.O., Udedibie, C., I h e shiulor, O.O.M. 2006 . Physiological responses of laying birds to Neem (Azadirachta indica) leaf meal based diets, body weight, organ characteristics and hematology. Online Journal Health and Allied Science. 2: 4 http//www.ojhas.org/issue 18/2006-24.htm.

Esonu, B.O., Ihekwumere, F.C., Emenalom, O.O., Uchegbu, M.C. and Etuk, E.B. 2002. Performance, nutrient utilization and organ characteristics of broilers fed Microdesmis puberula leaf meal. Livestock Research for Rural Development, 14(16)146. www.cipar.org.collirrd/irrd14/6/eson.1 46.htm.

Kale, B.P., Kothekar, M.A., Tayade, H.P., Jaju, J.B. and Mateeddin, M. 2003. Indian J. Pharmacol 35,177.

Kausik, B., Ishita, C., Ranajit, K.B. and Uday, B. 2008. Biological activities and medicinal properties of Neem (Azadirachta indica). Review article.

Obikaonu, H.O., Opara, M.N. Okoli, I.C. Okoro, V.M. Ogbuewu, I.P. Etuk E. B. and Udedibie. A.B.I. 2012. Haematological and serum biochemical indices of starter broilers fed leaf meal of neem (Azadirachta indica). JAgric.Techn, 8(1):71-79.URL http://www.ojafr.ir/main/attachments/ article/73/OJ.

Obikaonu, H.O. 2009. Production performance of and auti-coccidial / 
effects in deep litter managed chickens fed neem (Azadirachta indica) leaf meal. Ph.D thesis,Federal University of Technology, Owerri Nigeria P.78.

Ogbuewu, I. P., Odoemelam, V.U., Obikaonu, H.O., Opara, M.N., Emenalom, O.O., Uchegbu, M.C., Okoli, I.C., Esonu, B.O., Iloeje, M.U. 2010. The growing importance of neem (Azadirachta indica A. Juss) in agriculture, industry, medicine and environment: A Review. Research Journal of Medicinal Plants. 3(2):1-27.

Ogbuewu, I.P., Okoli, I.C. and Iloeje, M.U. 2009. Semen quality characteristics, reaction time, testis weight and seminiferous tubule diameter of buck rabbits fed neem (Azadirachta indica A Juss) leaf meal based diets. Iranian Journal of Reproductive Medicine. 7(1): 23-28.

Schumacher, M. Claudia,C.Simone, R. Mario, D. and Marc, D. 2011. Antiinflammatory, pro-apoptotic, and antiproliferative effects of a methanolic neem (Azadirachta indica) leaf extract are mediated via modulation of the nuclear factor- B pathway. Genes Nutr. (2011) 6:149-160.

SPSS 2008. Statistical Package for Social Sciences SPSS, 17.0.1 Version. Inc. Chicago IL.

Received: 12/01/13 Accepted: 05/09/13 